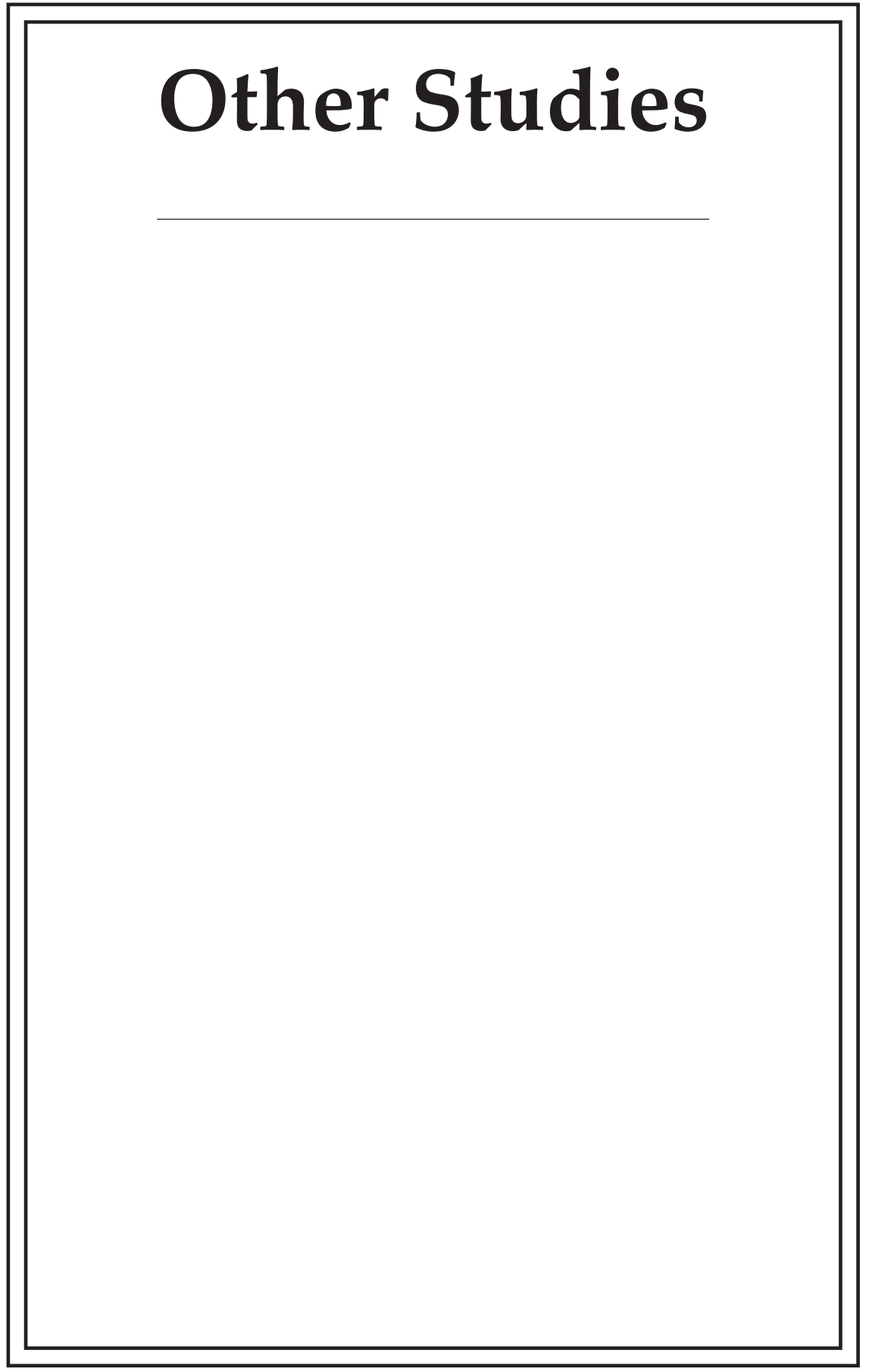

Downloaded from Brill.com๑4/26/2023 ๑2:45:29PM 


\section{THE LEGEND OF THE TWELVE FRIDAYS AND QUATTUOR TEMPORA*}

\section{Index of manuscripts}
A - MS Beograd, Narodna biblioteka Srbije, 200
B - Prague, Národní muzeum, IX.H.16
C - Siena, Biblioteca comunale, Ms. X.VI.13
D - Zagreb, Archiv HAZU, VII 32
E - Zagreb, Archiv HAZU, IV a 120
F - Russian National Library, Sofijskoje sobranije, 1264
G - State Historical Museum, Sinodal'noje sobranije, 830
I - Kyiv, St. Michael's Golden-Domed Monastery Library, 1643
J - Kungliga biblioteket, Stockholm, A 797
K - Archive of Ancient Relics, Institute of Russian Literature (Pushkinskij Dom), Severodvinskoje sobranije, 671
L - Russian National Library, sobranije Vyazemskogo, O 30
M - Russian National Library, F.p.I.121
N - Beograd, Narodna biblioteka Srbije, 632

The legend of the Twelve Fridays is a very interesting tradition with a long and very complex history. One of the most intriguing problems which it presents to the researcher is that of interrelationship between its local versions. This paper aims to investigate a minor point which, nevertheless, could clarify the nature and the scope of some correspondences that link together various traditions.

The immediate impetus for this study comes from the paper by Basil Lourié published in the recent supplementary volume to Scrinium. ${ }^{1}$

$\left(^{*}\right)$ This article was written as a part of the project, "Text transformation in the oral and written tradition," within the framework of the program, "Traditions and innovations in history and culture," launched at the Department of Historical and Philological Sciences, Russian Academy of Sciences.

(1) B. LouRIÉ, "Friday Veneration in Sixth- and Seventh-Century Christianity and Christian Legends about the Conversion of Nağrān," in The Coming of the Comforter: When, where, and to whom? Studies on the Rise of Islam and Vari- 
In particular, he argues for a Syriac background of the expression "seasonal" Friday in the Slavic texts. In this paper, I shall offer a different explanation which invokes not Eastern, but Western associations.

A few words are called for with regard to Lourié's hypothesis. Although it would be out of place here to go into a comprehensive discussion, I must make my own position clear. I have to admit that I do not believe in the Syriac origin of the legend, and Lourié's arguments seem to me rather unconvincing for several reasons. Firstly, it seems awkward to reconstruct a (Greek) prototype of the sixth century on the basis of texts written mostly in Latin and Slavic that are preserved in manuscripts starting from the eleventh (for the Latin texts) and the thirteenth (for the Slavic texts) centuries. Secondly, the Greek branch of the Twelve Fridays tradition poses many problems. Lourié seems to imply (tacitly, as it is not expressly stated in his paper) that the Slavic versions (of the so called "Eleutherian" type) go back to a Greek version which in turn was translated from a Syriac original. One should be reminded, though, that there are only three extant Greek copies of the legend, ${ }^{2}$ all of them preserved in relatively late manuscripts, and, besides, all three belong to the "Clementine" type (that is, distinctly Latin-oriented), while the "Eleutherian" type of the earliest Slavic tradition still has not been shown to have any clear Greek correspondence. ${ }^{3}$ Although it is possible that the Slavic version derives from a Greek prototype given that it is the most frequent scenario for Slavic texts in general, it is not at all an established fact in this case. I would also like to emphasize that two of the three Greek manuscripts containing the legend come from the Southern Italian milieu which could indicate deep ties and intensive interrelation with the Latin world. Some evidence of these links will be discussed later with regard to

ous Other Topics in Memory of John Wansbrough (OJC, 3), ed. by C. A. SEgovia, B. LounIÉ, Piscataway, NJ, 2012, pp. 131-230.

(2) These are MSS Biblioteca Apostolica Vaticana, Vat. gr. 1538 (15th cent.; a fragment was published by I. B. PIтRA, Juris ecclesiastici Graecorum Historia et Monumenta, t. 1, Romae, 1864, p. 301; for the complete text see G. Mercati, Note di letteratura biblica e cristiana antica (Studi e testi, 5), Roma, 1901, pp. 238-241; Vat. gr. 1276 (14th cent.) and Trinity College, Cambridge, O. 8.33 (16th cent.). The presence of the Greek text of the Twelve Fridays legend in the latter two MSS has not been noted until recently; currently I am preparing an edition of these copies.

(3) I refer the reader to the survey of the various recensions and previous research in the paper by LouRlé, "Friday Veneration," pp. 136-150. 
one of the aforementioned manuscripts. Some of the arguments presented in favor of the oriental hypothesis do not seem too plausible either, especially that of John Zosimos whose calendar is said to be "a witness, certain even if indirect, of the authority of the Twelve-Friday calendar for pre-eighth-century Palestine." ${ }^{4}$ The specific section of this text which is allegedly centered upon Friday veneration, in fact, does not mention any Fridays at all; it lists fourteen (not twelve) feasts, and many of them are clearly local (e.g. sancti Sabae, sancti Charitonis, sancti Cononis, Moysis). ${ }^{5}$ It is difficult for me to see here a connection not only with the Twelve Fridays legend as represented in the extant texts, but even with Friday veneration in general. The statement that "practice of 56-day fasts is a development emerging from the practice of specific Friday fasts" ${ }^{6}$ needs, I think, a more thorough elaboration than the one we find in the article in question. As for the calendar of the Twelve Fridays itself, the situation is far from being as simple as the author would have us think. Indeed, to obtain a clear picture of the set and nomenclature of the feasts to which Friday fasts are linked, with all their fluctuations, the material of all separate traditions (in Latin, Slavic and vernacular European languages) should be studied in full, or at least in their earliest forms. As of yet, no research of this kind has been made, and this fact makes the conclusions based on the material collected by Veselovsky ${ }^{7}$ premature and very likely subject to

(4) Lourié, "Friday Veneration," p. 162.

(5) G. Garitte, Le calendrier palestino-géorgien du Sinaiticus 34 (Xe siècle) (SH, 30), Bruxelles, 1958, pp. 119-120.

(6) Lourié, “Friday Veneration,” p. 160.

(7) А. ВЕСЕлОвСКИй, “Опыты по истории развития христианской легенды. II. Берта, Анастасия и Пятница. Гл. IV: Сказание о 12 пятницах" [Essays on the History of the Development of the Christian Legend. II: Berta, Anastasia, and Friday. Ch. IV: Narration on the 12 Fridays]," ЖМНП, 185 (1876), С. 326-367; іDEм, “гл. VI: Freiheit - Элевферий” [Freiheit - Eleutherius], ЖМНП, 191 (1877), С. 76-125. It is clear that this study, although brilliant and advanced for its time, now should be taken cautiously on account of a great bulk of material added since then. It is especially true for the Western tradition: as I have shown elsewhere (S. V. Ivanov, "The Legend of Twelve Golden Fridays in the Western Manuscripts. Part I: Latin," in: Colloquia classica et indogermanica - $V$, Acta linguistica Petropolitana. Труды ИЛИ РАН, Т. 7, часть 1, ред. Н. А. БОНдАРКО, Н. Н. КАЗАНСКИЙ, Санкт-Петербург, 2011, C. 561-572), there are more than fifty copies of the legend text in Latin alone, twelve of which have been published. Thus, for example, in Lourié's paper, the Latin prototype is reconstructed on the grounds of a single MS Vat. lat. 
later revision. In conclusion, I should say that I find deep reconstruction of the Twelve Fridays legend on the level of the sixth century and with Oriental (Syriac or Arabic) affiliation neither possible nor necessary, but, nevertheless, these attempts could be useful since they are provoking discussions and stirring up interest in the textual history of such a complex and intriguing phenomenon as the tale of the Twelve Fridays.

Now I will proceed to the subject of this paper, which is a rather narrow one. I will investigate the designation вргменная, 'seasonal or temporary' (cf. Russian время 'time') applied to some Fridays in the Slavic texts of the Twelve Fridays legend. It should be noted that it is not a common designation, and its meaning has not been explained so far. Therefore, it seems that the best way to treat this topic is to start with listing our evidence. Below for the sake of brevity I will cite only those fragments that contain this designation, providing only the number for the Friday entry in which they are found.

The earliest attestation of this term comes from the Cyrillic MS Beograd, Narodna biblioteka, 200 (14th cent. henceforth - A), ${ }^{8}$ where one finds the following descriptions:

1) Петькь .в. <=2> по вьздвижени крьста. [...] си есть петькь троврЂменьны, того ради велить хрьстиянину поститыи се

'The second Friday after the Exaltation of the Holy Cross. It is the third seasonal Friday, that is why a Christian is obliged to fast $<$ on this day $>^{\prime}$

2) Петькь .д. $<=4>$ мъсеца дек<абря> по рождьствъ христовъ. [...] си есть петькь четвороврьменьни, то <го $>$ рад $<$ и $>$ велить крьстиянину постити се срђду, понед<ъдьникь>, петькь и причестыти се кь аврамовъмь дьнемь

'The fourth Friday in the month of December after Christmas. This is the fourth seasonal Friday. That is why a Christian is obliged to fast on Wednesday, Monday < and > Friday and to be counted among Abraham's days'

3) Петькь .é. <=5> мЂсеца марьта .а. <=1> петькь. [...] си есть петькь прьвоврђменьны, того ради велитьь крьстиянину постыти се

3838 used by Veselovsky which is unique in designating the ninth Friday as a Friday "post festum sanctorum Iacobi et Christofori": all other Latin MSS refer to a Friday "post natiuitate apostolorum."

(8) S. NovaKović, “Dvanaest petaka," Starine, 4 (1872), pp. 24-28. 
'The fifth Friday <is> the first Friday of the month of March. This is the first seasonal Friday. That is why a Christian is obliged to fast <on this day $>^{\prime}$

4) Петькь .ే. <=9> прбжде пеньтикостие. [...] си есть петькь дьвоврбменьны, того ради велить крьстиянину постыти се

'The ninth Friday before Pentecost. This is the second seasonal Friday. That is why a Christian is obliged to fast <on this day $>^{\prime}$

Сие же светы отьцы прозрьвьше духомь светимь, тако повелъше сьблюсты е постомь по .г. <=3> дьны, и тако улучити причестие и с нимь радующе се станемь одесьную самого Христа, да аще кьто сьблюдеть сия четвороврьменая о хльбъ и о водь, то и вь страшьны дьнь не убоить се никоего же страха ${ }^{9}$

'This is what the holy Fathers perceived through the Holy Spirit, and they ordered to observe them fasting for three days and thus to take part <in their knowledge>, and we will gladly stand at the right hand of Christ, and whoever will observe this četvorovrêmenaja $<$ four-seasonal $>$ fasting of bread and water, he will not have to be afraid of anything on the Judgment Day.'

It should be noted that the order of Fridays in this text may have been corrupted due to their adaptation to the Byzantine liturgical year which started on the 1st of September, but the fact that this was not the original arrangement can be inferred from the use of such designations as прьвовртиеньны ('first seasonal'), дьвовртьменьны ('second season$\mathrm{al}^{\prime}$ ), тровртьменьны ('third seasonal') and четворовртьменьни ('fourth seasonal') where the numbers are in accordance with the calendar beginning in March rather than September. Anyway, whatever the original arrangement may have been, the four 'seasonal' Fridays are to be arranged as follows: 1. the first Friday of March; 2. a Friday before Pentecost; 3. a Friday after the Exaltation of the Holy Cross (the 14th of September); 4. a Friday in December. The expression четвороврпменая in the concluding fragment deserves special attention as it shows that this term covers all the previously mentioned designations, and we will return to it later.

(9) Henceforth I shall use for the Cyrillic material a simplified transcription which is sufficient for the purposes of the present study. All translations, if not otherwise stated, are mine. 
Largely the same account is to be found in the Cyrillic MS Prague, Národní muzeum, IX.H.16 (15th cent., henceforth - B). ${ }^{10}$

The next two attestations occur in two Glagolitic copies from the MSS Siena, Biblioteca comunale, X.VI.13 (15th cent., henceforth - C) and Zagreb, Archiv HAZU VII 32 (Grškovićev zbornik, 16th cent., henceforth $-\mathrm{D})$. They are very close to each other, and below we shall reproduce the relevant fragments only from the Siena text: ${ }^{11}$

1) .B. $<=2>$ petakb po vzdviženii $s<v e>t<a>$ go križa [...]. Si petakb $\mathrm{e}<$ stb $>$ č $<\mathrm{e}>$ tvrtidnevan' zato veli se $\mathrm{h}<$ rbst $>$ sêninu postiti

'The second Friday after the Exaltation of the Holy Cross. This Friday is $\check{c}<e>$ tortidnevan' $<$ of the four days $>$, that is why a Christian is obliged to fast $<$ on this day $>$

2) .G. $<=4>$ petakь e $<$ stb $>$ miseca dektebra $v$ kvatri pred ro $<i>$ stvom' $\mathrm{H}<$ rbsto>vimb [...] Si petakb est' četvrtodnevanı i vrimenan'. Togo radi veli se $h<$ rbst $>$ bêninu postiti

'The fourth Friday is in the month of December in kvatri before Christmas. This Friday is četvrtodnevan $<<$ of the four days $>$ and seasonal, that is why a Christian is obliged to fast <on this day $>$ '

3). Z. $<=9>$ petakb e $<$ stb $>$ po petikostihь $[\ldots]$ i si petakb vrimenanb $\mathrm{e}<\mathrm{stb}>$. Togo radi veli se $\mathrm{h}<$ rbst $>$ bêninu postiti

'The ninth Friday is after Pentecost. And this Friday is seasonal, that is why a Christian is obliged to fast <on this day $>$ '

...Ako li v sie pet'ki ili $\mathrm{v}$ kvatri tempornê začnet se i rododit se $<$ dite> budêt' nêzdravo ili bêsno ili hromo ili gluho ili nimo ili slipo ili inu bolezniju udržimo. I ovo slišavše $s<v e>t i o<t_{b}>c i$ naučeni duhom' s<ve >timb, zapovidašê da ki godi budet' streci i čuvati ove pêtke zgora pisane i .g. $<=4>$ kvatri tem'pori postiti o vode i o krusi, $\mathrm{k}<\mathrm{a}>\mathrm{ko}$ e zgora pisano $\mathrm{v}$ strašni $\mathrm{d}<\mathrm{a}>\mathrm{nb}$ suda ne uboit' se...

'And if a child is conceived or born on those Fridays or kvatri tempornê, he will be ill or demented or lame or deaf or dumb or blind or obsessed with other disease. And the Fathers who heard that and were instructed by the Holy Spirit, commanded that whoever will observe those aforementioned Fridays and fast four kvatri tem'pori on water and bread, as is written above, will not be afraid of the condemnation on the Judgment Day.

(10) G. PolívKA, “Opisi i izvodi iz nekoliko jugoslavenskih rukopisa u Pragu," Starine, 12 (1890), pp. 195-220.

(11) A. NAzor, "Još jedan glagoljski tekst Legende o 12 petaka," Croatica. Prinosi proučavanju hrvatske književnosti, 42/43/44 (1996), pp. 289-299. 
It is clear that these two Glagolitic copies correspond to $\mathrm{AB}$ in counting September as the first month of the year. However, there are two important points that differentiate this account from AB. First of all, while in the Cyrillic texts we find only the designations прьвоврименьны ('first seasonal'), дьвовримменьны ('second seasonal'), тровргименьны ('third seasonal') and четворовргменьни ('fourth seasonal'), the Glagolitic counterparts give us such expressions as čcetvrtidnevan' ('of the four days'), četortodnevano $i$ vrimenan' ('of the four days and seasonal') and simply vrimenans ('seasonal'). I think all these fluctuations could be explained as ultimately deriving from $\mathrm{AB}$ четворовргменьни, since vrimenan' in this case might be a contracted form of the terms used in A, and četvrtodnevanı may be an analogous form based on четвороврпменьни, with dапь ('day') instead of vremja ('time'); see discussion below. It is all the more possible since četortodnevan no commonly recognized meaning and is used in the same context as четвороврименьни. The second difference is that the Glagolitic texts have only three 'seasonal' Fridays rather than four as in $\mathrm{AB}$.

Comparing the concluding passages of $\mathrm{CD}$ and $\mathrm{AB}$, we can see that the expression $\mathrm{CD} 4$ kvatri tem'pori corresponds to $\mathrm{AB}$ четвороврпименая. I will return to this correspondence later.

The last Glagolitic text which concerns us here is the copy from MS Zagreb, HAZU IV a 120 (Tkonski zbornik, 16th cent., henceforth E), ${ }^{12}$ which preserves only a fragmentary witness to the presence of the 'seasonal' Fridays, ${ }^{13}$ but it is to be explained as a result of a later abridgement since as a whole this text is very close to $C$ and $D$.

(12) R. Strohal, Stare hrvatske apokrifne priče i legende, U Bjelovaru, 1917, pp. 22-24.

(13) Only for the ninth Friday: Deveti pet(a)k est po petikostih <...> petak vrimenni. Sego cić krstjaninu postiti. 'The ninth Friday is after Pentecost. And this Friday is seasonal, that is why a Christian should fast [on this day]'; and in the concluding part: Ako li v simi petki ili v kvatri temporni začnet se dite, budet nezdravo ili besno ili nemo ili hromo ili slepo ili knasto ili inu bolezanju obdržano. I ovo slišavše s(ve)ti otci naučeni Duhom S(ve)tim zapovidaše da ki godi bude strići i čuvati ove petke i četvere kvatri temporne postiti u krusi i o vodi, kako e više pisano, v strašni d(a)n Sudni ne uboi se biti osujen6. 'And if a child is conceived on those Fridays or kvatri temporni, he will be ill or demented or dumb or lame or blind or deaf or obsessed with other disease. And the Fathers who heard that and were instructed by the Holy Spirit, commanded that whoever will observe those Fridays and fast four kvatri temporne on bread and water, as is written above, will not be afraid of the condemnation on the Judgment Day. 
For the next evidence, we should turn to the Russian manuscripts. Here we find a copy from MS Russian National Library, Sofijskoje sobranije, 1264 (15th cent., henceforth $-\mathrm{F}) .{ }^{14}$

1) Шестая пятница преже мясопуста [...] Сиже бывает пятница въ .в. <=2> июля. тоже временъная

'The sixth Friday before Meatfare Week. It is a Friday which occurs in the second <week> of July, also seasonal'

2) Десятая пятъница по въздвижении честнаго креста [...] тоже временъная

'The tenth Friday after the Exaltation of the True Cross, also seasonal'

3) Втораянадесять пятница по рожестъвъ Христовъ [...] тоже врем<енъная>

'The twelfth Friday after Christmas, also seasonal'

As we can see, here only three 'seasonal' Fridays are mentioned, as in $C$ and $D$, but the situation is further complicated by the fact that the first passage where this term occurs is clearly corrupted: $\mathcal{M}$ sconycm (Meatfare Week) is the second week before Lent, and this gives us a date somewhere in January or February, while the general context and the unambiguous reference further in the passage points to July. The mention of $\mathcal{M}$ sconycm is an obvious scribal error which arose from contamination with the following phrase which can be read in the concluding part of this section: сего ради латыняне поют аллилуию а ни славу отию и сыну недплею преже нашего мясопуста 'This is why the Latins sing alleluia instead of Gloria Patri a week before our myasopust'. We should probably read not мясопуст, but пентекост ('Pentecost') in the introducing sentence; this reading is corroborated by other copies (primarily A).

However, the wording and the syntax of the phrase $в\urcorner . \vec{B} .(=2)$ июля seem suspiciously ambiguous: it is not possible that a strict date (July 2 ) is meant here, since it is obvious that July 2 would not necessarily fall on a Friday. Therefore the most probable solution is that the preposition $b r$ ('in, on') here arose from doubling the numeral . $\vec{B}$. ('two'), because both preposition and numeral are designated by the same letter 6 in writing. Moreover, the reference to July also causes some problems, as the next, seventh Friday, is said to be before the feast of Peter and

(14) Н. С. Тихонравов, Памятники отреченной русской хитературы [Monuments of the Apocryphal Russian Literature], Москва, 1863, Т. 2, с. 323-338. 
Paul which is celebrated on June 29. Therefore, the sixth Friday cannot be in July. This place in the MS is obviously corrupt, and probably one should read here пятница. $\vec{в} .<=2>$ июня 'the second Friday in June' instead of пятница вь . $\vec{в} .<=2>$ июля. This reading is corroborated by the text of Ukrainian provenance (see below, note 16) which is very close to $\mathrm{F}$ and which reads in this place $. \vec{s} .<=6>$ пятниц м мпсяи а июня.$\vec{B}$. $<=2>$ 'the sixth Friday $<$ is $>$ the second in the month of June'.

A slightly different account is to be found in the MS State Historical Museum, Sinodal'noje sobranije, 830 (16th cent., henceforth - G): ${ }^{15}$

1) .á. $<=1>$ пят<ница> мбсяца марта [...] сии же пят<ница> .á. $<=1>$ временная и тоя дЂля поститися в понедЂдьник и в среду и в пят<ницу> и причтется ко аврамовым. $\overrightarrow{\text { дi. }}<=14>$ родомъ

'The first Friday of the month of March. This is the first seasonal Friday and on account of this $<$ Friday it is proper $>$ to fast on Monday and on Wednesday and on Friday, and he <who will do so $>$ will be counted among the fourteen generations of Abraham'.

2) .ё.я $<=5>$ июня $[\ldots]$ си пят<ница $>$.в.я $<=2>$ времянъная и тоя дъдя пят<ницы> поститися мъсяца июня .Бे. $<=2>$ недъди в пон<едЂдьник> в среду в пят<ницу> и причеститися къ давыдовымъ .д. $<=4>$ родомъ

'The fifth $<$ Friday $>$ in June. This Friday is the second seasonal, and on account of this Friday <it is proper $>$ to fast in the second week of the month June on Monday <and > on Wednesday <and > on Friday and to be counted among the four generations of David.'

3) $. \dot{6} . я<=9>$ пя<тница $>$ пред здвижениемь честнаго креста [...] си же пят<ница $>$. ститися. Г. $е$ еe $<=3>$ недъди в понед $<$ Бльник $>$ в среду в пят $<$ ницу $>$ и причтися къ .ді. $<=14>$ родом иже по преселенья вавилоньстьм

'The ninth Friday before the Exaltation of the True Cross. It is the third seasonal Friday, and on account of this Friday <it is proper> to fast in the third week on Monday <and> on Wednesday $<$ and $>$ on Friday and to be counted among the fourteen generations which were after the Babylonian captivity.'

4) .ві. <=12> пят<ница> по рождествъ по Христовъ [...] си же пят<ница $>$.д.я $<=4>$ временъная и $<$ тоя $>$ дЂля пятьници поститися мъсяца декабря .д.я <=4> недъди въ понед<ьдьник> в среду в пят<ницу> и причтитися къ Христову рождеству

'The twelfth Friday after Christmas. It is the fourth seasonal Friday, and on account of <this $>$ Friday <it is proper $>$ to fast in

(15) ТихонРАвов, Памятники, с. 327-335. 
the fourth week of the month of December on Monday <and> on Wednesday <and> on Friday and to take part in Christ's Nativity.'

To these Russian MSS we should add MS St. Michael's Golden-Domed Monastery Library 1643 (the year 1604, henceforth - I) ${ }^{16}$ where the list of seasonal Fridays corresponds to F, and two more MSS which are very close to $G$, so there is no need to cite relevant passages from them. These are MS Kungliga biblioteket, Stockholm, A 797 (16th cent., henceforth $-\mathrm{J})^{17}$ and MS Archive of Ancient Relics, Institute of Russian Literature (Pushkinskij Dom), Severodvinskoje sobranije, 671 (early 18th cent., henceforth $-\mathrm{K}) .{ }^{18}$ The only point that should be made is that it is the only copy where the designation 'seasonal' is mentioned in the title which reads Сказание святаго Эльферия о двоюнадесять пятницахь о временныхь ('The Narration of St Eleutherius on the Twelve Seasonal Fridays'). We should also refer to the text of the MS Russian National Library, sobranije Vyazemskogo, O 30

(16) С. Шевченко, “Елевферієвська редакція «Сказанія о 12 пятницах» і український список «Сказанія» p. 1604," [The Eleutherian recension of the "Twelve Fridays legend" and the Ukrainian text of the "Legend" from the year 1604], Записки Украйнського Наукового Товариства, 2 (1908), pp. 23-27: 1) .s. (=6) пятница мъсяца июня .ъ. $(=2)$ [...] се же временная 'the sixth Friday (is) the second in the month of June. It is a seasonal (Friday)' 2) .i. (=10) пятница сентеврия по въздвижении честнаго креста. се же временная. 'the tenth Friday in September after the Exaltation of the True Cross, it is a seasonal (Friday)' 3) .в̈. (=12) пятница пред рожеством Христовымъ. сия же временная 'the twelfth Friday before Christmas. This is a seasonal (Friday).'

(17) On this MS see M. В. РОЖдественСКАя, “АПокрифы в сборнике XVI в. из Стокгольмской Королевской библиотеки (А 797)" [Аросrуpha in the manuscript of the 16th century from the Royal Library of Sweden (A 797)], ТОДРА, 55 (2004), pp. 387-394.

(18) Unpublished; the edition is being prepared by the present author. It should be noted that $\mathrm{K}$ differs from $\mathrm{G}$ in assigning the tenth Friday after the Exaltation of True Cross, most probably, due to a scribal error. On the relationships between G, J and K see C. В. Иванов, “«Сказание о 12 пятницах» и «Сон царя Иоаса»: взаимодействие двух апокрифических текстов" [“Тhе Legend of the Twelve Fridays" and "The Vision of Jehoash": on the interaction of two apocryphal texts], in Индоевропейское языкознание и классическая филология - XV. Материалы чтений, посвященных памяти профессора Иосифа Моисеевича Тронского. 20-22 июня 2011, ed. by Н. Н. КАзАнский, St Petersburg, 2011, pp. 211-220. 
(17th cent., henceforth - L) ${ }_{1}^{19}$ which does not apply the term 'seasonal' to the Fridays in the list, but reserves this designation for the concluding section:

Се же временные пятницы .Ві. <=12> тако подобаетъ блюсти

'These seasonal twelve Fridays one should observe like this.'

There are two more pieces of evidence to be mentioned. The first of them comes from the MS Russian National Library, F.p. I. 121 (third quarter of the 14th cent., henceforth $-\mathrm{M}) \cdot{ }^{20}$ It is a Cyrillic (Serbian) manuscript which contains the text of the Twelve Fridays legend. However, several pages of this text were torn off (presumably, due to the apocryphal nature of the legend), and we are left with only a few lines of the concluding fragment. Nevertheless, the wording is very close to $\mathrm{A},{ }^{21}$ and it gives rise to the suggestion that the rest of the text was also similar to it. And, at last, there is the oldest Slavic copy of the legend preserved in the MS Beograd, Narodna biblioteka Srbije,

(19) В. Н. ПЕРетЦ, Новые труды по источниковедению древне-русской литературь. Критико-библиографический обзор I-VIII [New source studies in the Old Russian literature. A critical and bibliographical survey I-VIII], Kiev, 1905, pp. 21-23.

(20) On the MS see A. А. Турилов, “ «Поучение Моисея» и сборник игумена Спиридона (новгородский памятник XII в. в контексте русскоюжнославянских связей)" ["Moses' Teaching" and the compilation of Abbot Spiridon (a Novgorod text of the 12th century in the context of Russian and South Slavic connections)], in Русистика. Славистика. Индоевропеистика. Сборник к 60-летию Андрея Анатольевича Зализняка [Rusian Studies. Slavic Studies. Indo-European Studies. Festschrift for A. A. Zaliznjak on his 60th anniversary], ed. by А. Гиппиус, Т. НиколАевА, В. Топоров, Москва, 1996, с. 83-104.

(21) Cf. the relevant passage: Сии же .ві. <=12> петькьь святыи отци позрђше духомь святыимь и тако повельше вь коеждо врђме поститисе по $. \vec{\Gamma} .<=3>$ днии и тако вьзможемь достигнути и причеститисе кь святому патриарьшьскому роду и с нимь утегнемь радующесе стати одесную самого иисуса христа иже сия .д.ро <=4> врьменнаа кто сьхранить о хльбъ и о водъ и о святои чистоть то никакоже вь страшныи день не боятисе никогоже страха [Our Holy Fathers perceived these twelve Fridays through the Holy Spirit, and they ordered to observe them every time fasting for three days and thus we will be able to reach and to belong to the Holy generation of patriarchs, and with them we will gladly stand at the right hand of Jesus Christ, and whoever will observe this četvorovrêmenaja (four-seasonal) fasting on bread and water and with holy chastity, will not be afraid of anything on the Judgment Day]. 
632 (late 13th cent., henceforth $-\mathrm{N}$ ), ${ }^{22}$ where one finds the following intriguing passage:
. s. $<=6>$ петькь пръдь марковъмь днемь [...] си же петькь .в. $<=2>$ июня мъсяца тогожде връмене
'The sixth Friday before the feast of St Mark. It is the second Friday of the month of June of the same time.'

The problems here are largely the same as those discussed with regard to the first Friday of $G$. The reference to the feast of St. Mark (April 25) contradicts both the general context and the concluding part of this sequence which places this Friday in June. Secondly, it is not clear how one should interpret the numeral in the phrase $\mathrm{cu}$ же петькь. $\vec{b} .<=2>$ июня миьсяиа. As I have suggested earlier, the numeral .$\vec{b}$. may stand for the preposition $b b$ which was reinterpreted as a number (and caused the genitive of the following nouns); then it would simply mean 'in the month of June'. However, it is also possible that this phrase could be interpreted as 'the second Friday of June', and this solution seems the most likely given the evidence from other texts and traditions (see below). And the most important point for our topic is the fact that the expression тогожде вртиене 'of the same time' most probably is to be linked to the phrase тоже временная 'also seasonal' of other texts. Then we should assume that this copy lost all the other designations for 'seasonal' Fridays and preserved only the one for the sixth Friday. It may well be so, especially given that the text seems to be heavily abridged in the list of the twelve Fridays.

Now, after presenting our evidence, we can make some general observations. First of all, it should be noted that the designation 'season$\mathrm{al}^{\prime}$ does not occur in all copies of the legend text. Nevertheless, it can be found in a significant amount of MSS, including the earliest ones and belonging to the different language and cultural branches of the Slavic tradition where this text had been transmitted: Serbian, Croa-

(22) М. Соколов, Материаль и залетки по старинной славянской литеpamype. Выпуск первый: I-V [Materials and notes on ancient Slavic literature. First issue: I-V], Москва, 1888, [Nr. III], с. 53-57. In fact, the oldest Slavic copy of the legend is that preserved in the Sinaic MS 34. It is unedited; the modern Bulgarian translation by A. Miltenova can be found in Balgarskata literatura i kniznina prez XIII v. [Bulgarian literature before the 13th century], Sofia, 1987, pp. 167-169. Since it remains unpublished, and I have had no chance to look into the MS, it should be left out of consideration here, but it is to be noted that, on account of the Bulgarian translation, it mentions the same four 'seasonal' Fridays as those discussed in this paper. 
tian, Russian, Ukrainian. Moreover, this feature (mention of 'seasonal' Fridays) could be regarded as instrumental in distinguishing different recensions. Furthermore, as we can see, this designation is applied not to all Fridays, but only to specific ones. The MSS evidence can be summarized in the following table:

\begin{tabular}{|l|l|l|l|l|l|l|}
\hline & F & I & G J & K & A B & C D \\
\hline $\begin{array}{l}\text { the first } \\
\text { Friday of } \\
\text { March }\end{array}$ & - & - & + & + & + & - \\
\hline & $\begin{array}{l}\text { the } \\
\text { second } \\
\text { Friday } \\
\text { of June }\end{array}$ & $\begin{array}{l}\text { the } \\
\text { second } \\
\text { Friday } \\
\text { of June }\end{array}$ & $\begin{array}{l}\text { in the } \\
\text { second } \\
\text { week } \\
\text { of June }\end{array}$ & $\begin{array}{l}\text { in the } \\
\text { second } \\
\text { week } \\
\text { of June }\end{array}$ & $\begin{array}{l}\text { before } \\
\text { Pente- } \\
\text { cost }\end{array}$ & $\begin{array}{l}\text { after } \\
\text { Pente- } \\
\text { cost }\end{array}$ \\
\hline $\begin{array}{l}\text { after the } \\
\text { Feast of } \\
\text { Exalta- } \\
\text { tion of } \\
\text { the Holy } \\
\text { Cross } \\
\text { (Septem- } \\
\text { ber, 27) }\end{array}$ & + & + & $\begin{array}{l}\text { before } \\
\text { the Exal- } \\
\text { tation of } \\
\text { the Holy } \\
\text { Cross }\end{array}$ & + & + & + \\
\hline $\begin{array}{l}\text { after } \\
\text { Christ- } \\
\text { mas }\end{array}$ & + & $\begin{array}{l}\text { before } \\
\text { Christ- } \\
\text { mas }\end{array}$ & + & + & + & $\begin{array}{l}\text { before } \\
\text { Christ- } \\
\text { mas }\end{array}$ \\
\hline
\end{tabular}

As can be seen, despite some differences, the number and the arrangement of 'seasonal' Fridays form a clearly discernible pattern. The first 'seasonal' Friday is the first Friday of March, although, it should be noted, this Friday is not mentioned in the MSS CDFI. The second Friday is the most variable, but the dates are grouped approximately around June in all MSS. However, such alignments as before Pentecost (AB) and after Pentecost (CD) deserve special attention. The third Friday is placed after the Exaltation of the True Cross in all MSS except $G$ where it occurs before this Feast. And, finally, the fourth Friday is to be observed around Christmas (after Christmas in ABFGJK; before Christmas in CDI).

This arrangement as well as the designation 'seasonal' invite a comparison with the Western fasts known as Quattuor Tempora. These sea-

(23) According to the adjusted version; see discussion above. 
sonal fasts originated in Rome at a very early stage, ${ }^{24}$ and then were accepted throughout the Western Church, but were never recognized in Eastern Christianity. Generally they are observed in the first, fourth, seventh, and tenth months of the year (thus, in March, June, September, and December). The exact dates were long a matter of controversy, and we will return to this question later. It is to be emphasized that the times prescribed for the Quattuor Tempora fasts directly correspond to those reserved for the 'seasonal' Fridays in the Slavic texts. Under these circumstances the term временная used for designating these particular Fridays (but for no others) seems to be an echo or maybe a translation of the Latin term Quattuor Tempora. The exact correspondence to this may be found in the concluding part of the texts in MSS ABCDEM where there occur such designations as сия четворовргменая $(\mathrm{ABM})$ and, even more significantly, četvere kvatri temporne (CDE). While четвороврименал is a calque from Quattuor Tempora, the designation četvere kvatri temporne preserves the Latin term in almost the original form, which is not surprising at all given that it occurs in the Glagolitic MSS of Croatian provenance, but adds a redundant translation of the first part of it (četvere). This redundant addition shows that the term kvatri temporne was taken over and perceived as a single lexical unit or at least as an idiomatic expression. The Slavic equivalent четвороврименая, however, was subject to a different development. The first part of this calque четворо came to be associated with the number 'the fourth', thus clearing the path for such new analogical formations as прьвоврименьнь ('first seasonal'), дьвоврияменьны ('second seasonal'), and тровргменьны ('third seasonal'). This development made the second part of the composite вртиеньны look like a separate term which was used to cover all the Quattuor Tempora Fridays. That this was a gradual and variable process is shown by the various designations found in $\mathrm{CD}$, such as č<e>tvrtidnevan', četortodnevans i vrimenan', and vrimenans which are obviously connected to четвороврпменая, but differentiate the terms vrimenan

(24) They are mentioned in the sermons of Leo the Great. On the Quattuor Tempora in general see G. G. WILLIS, Essays in Early Roman Liturgy (Alcuin Club, 46), London, 1964; L. FIsCHER, Die kirchlichen Quatember. Ihre Entstehung, Entwicklung und Bedeutung in liturgischer, rechtlicher und kulturhistorischer Hinsicht (Veröffentlichungen aus dem kirchenhistorischen Seminar München, IV. Reihe, No. 3), München, 1914.

(25) It is interesting to note the occurrence of the term kvatri in CD: miseca dektebra v kvatri pred ro[i]stvom' $\mathrm{H}<\mathrm{rbsto}>\mathrm{vimb}$ 'in the month of Decem- 
Quattuor Tempora were not restricted to Fridays. The strict fast should be observed on Wednesday, Friday, and Saturday of the week. This institution explains otherwise vague allusions found in ABGJK which prescribe постити се српду, понед<пльникь>, петькь 'to fast on Wednesday, Monday <and> Friday' ${ }^{26}$ the three fast-days of the week are mentioned also in the concluding sections of ABM: повелпше сьблюсты е постомь по .г. $<=3>$ дни / повелпше вь коеждо вртиме поститисе по .2. $<=3>$ днии 'ordered to observe them fasting for three days / ordered to observe them every time fasting for three days'. The only difference lies in the fact that Slavic versions substitute понед<пльникь> 'Monday' for Saturday - a development which is difficult to account for. However, the general pattern of three fasting days remained intact.

The same MSS ABGJK ${ }^{27}$ after mentioning these three fasting days continue with a mysterious addition:

поститися в понедъдьник и в среду и в пят<ницу> и причтется ко аврамовым.дї. <=14> родомъ

'to fast on Monday and on Wednesday and on Friday, and he $<$ who will do so $>$ will be counted among the fourteen generations of Abraham'

поститися мъсяца июня .в. <=2> недъди в пон<едъдьник> в среду в пят<ницу> и причеститися къ давыдовымъ .д. <=4> родомъ

'to fast in the second week of the month June on Monday <and> on Wednesday <and> on Friday and to be counted among the four generations of David'

ber in kvatri before Christmas'. It may be that kvatri here also means Quattuor Tempora, being an abridgement of CDE kvatri temporne, but, as suggested by one of the referees, to whom I am very grateful for this suggestion, most probably it refers to the four weeks of Advent.

(26) In $A B$ this prescription is mentioned regarding only the December Friday, but in GJK it is applied to all four 'seasonal' Fridays.

(27) In fact, $\mathrm{AB}$ mention only Abraham: и причестыти се кь аврамовюми дьнемь 'and to be counted among Abraham's days', but it is clear that this reference originated in the tradition discussed here. However, one cannot be certain at which stage of the text transmission of the references to the other generations were lost. Also note the different wording: $\mathrm{AB} \kappa$ вврамовими дьнемь 'among Abraham's days' vs. GJK ко аврамовым .Ji. <=14> pодоми 'among the fourteen generations of Abraham.' 
поститися .г.ее <=3> недЂди в понед<Ћдьник> в среду в пят<ницу> и причтися къ .діi. <=14> родом иже по преселенья вавилоньстьм

'to fast in the third week on Monday <and> on Wednesday $<$ and $>$ on Friday and to be counted among the fourteen generations which were after the Babylonian captivity'

поститися мъсяца декабря .д.я <=4> недъди въ понед<ъдьник> в среду в пят<ницу> и причтитися къ Христову рождеству

'to fast in the fourth week of the month of December on Monday $<$ and $>$ on Wednesday <and $>$ on Friday and to take part in Christ's Nativity'

It seems that now we can explain the meaning of these references to the generations of Abraham, David, the Babylon captivity and the Nativity of Christ by taking into account a parallel from the Quattuor Tempora exegesis. As Fischer observed ${ }^{28}$ it was a usual custom of medieval liturgists to give a symbolical interpretation of periods separating the single Tempora in terms of generations alluded to in the genealogy of Christ, and namely in Mt 1, 17 (translation from the King James Version):

So all the generations from Abraham to David are fourteen generations; and from David until the carrying away into Babylon are fourteen generations; and from the carrying away into Babylon unto Christ are fourteen generations.

Since each Quattuor Tempora week is separated from the others by the distance of 14 weeks, these periods came to be symbolically equated with the thrice fourteen generations from Abraham till Christ. This symbolic interpretation fits perfectly well into the pattern offered in GJK where each 'seasonal' Friday is marked with reference to 1) fourteen generations of Abraham; 2) fourteen ${ }^{29}$ generations of David; 3) fourteen generations after the Babylon captivity; 4) the Nativity of Christ.

Returning to the calendar dates of the Quattuor Tempora, it is to be noted that originally there were Tria Tempora, rather than Quattuor. The earliest references "mention the fasts of the fourth, seventh, and tenth

(28) FISCHER, Die kirchlichen Quatember, p. 158, n. 1. See also the references to Amalarius, Durandus and Garnerius, listed by Fischer.

(29) The reading ..$<=4>$ in $G$ is obviously a corruption instead of .$\partial i$. $<=14>$. The original reading $. \delta i .<=14>$ is preserved in J and K. 
months, and the fast of the first month was a later addition," 30 which was introduced in any case before 600 . This evidence invites comparison with the Slavic material where, as we have seen earlier, the March fast is absent from some texts (namely CDFI). This absence requires an explanation: we could offer a somewhat mechanical argument and suggest that the first fast was omitted in the course of the text transmission due to abridgements or scribal errors, but the fact that in the earliest Latin tradition there was no fast in March makes legitimate a different question: could it be that the Slavic variant mentioning only three 'seasonal' Fridays was not the result of abridgement, but reflected an earlier Latin tradition of Tria Tempora? Of course, this is a highly hypothetical possibility; however, it seems absolutely legitimate to speculate on it.

The exact dates of the Quattuor Tempora fasts were long debated within the Western Church. As Willis observes, there existed two different systems. "One system is to have the Ember Fasts in the first, fourth, seventh, and tenth months of the civil year, which develops into the system later set forth by Amalarius and some of the Roman Ordines, according to which the fasts are in the first week of March, the second week of June, the third week of September, and the fourth week of December. The other is to integrate these fasts as far as possible into the liturgical year, having the first in the first week of Lent, the second during the week after Pentecost, and the fourth in the third week of a four-week Advent; the third fast in September remaining in the third week of that month, since there is no ecclesiastical season to which to attach it." 31

The same fluctuations can be found in the distribution and arrangement of the Slavic 'seasonal' Fridays. The mixture of the monthly alignment with the liturgical calendar can be seen in $G$, where it is prescribed, in full accord with the first pattern, to fast in the first week of March, in the second week of June, in the third week of September, and in the fourth week of December, although the third and the fourth 'seasonal' Fridays are linked not to months (September and December), but to the Feast of the True Cross and Christmas. It is worth noting that all the Slavic texts which mention four 'seasonal' Fridays invariably place the first 'seasonal' Friday in the first week of March, and Lent is not referred to anywhere.

(30) Willis, Essays in Early Roman Liturgy, p. 57.

(31) Ibid., p. 60. 
I think this evidence convincingly shows that 1) the Slavic texts on the Twelve Fridays were influenced by the Latin tradition of the Quattuor Tempora fasts; 2) the designation вргмиенные is to be derived from the Latin Quattuor Tempora; 3) this designation cannot be taken as an argument in favor of the Syriac origin of the Twelve Fridays legend.

These results can provide some insight on the Slavic legend of the Twelve Fridays as a composite text. It is significant that in the Russian tradition we find a text which provides striking parallels with the Twelve Fridays legend, but obviously circulated as a separate tradition. It was published by M. Sokolov from the MS Russian National Library, Sofijskoje sobranije $1462,82 \mathrm{v}-83 \mathrm{r}$ (16th cent.). ${ }^{32}$

Мъсяца марта постися первыя недъди въ понедъльникъ, въ среду и въ пятокъ: да причтется къ 14 родовъ Авраамлихъ. Вешнихъ дней.

Мъсяца июня постися двъ недъди въ понедъдьникъ, въ среду и въ пятокъ: да причтется къ 14 родовъ Давидовыхъ. Пътнихъ дней.

Мъсяца сентября постися три недъди въ понедъдьникъ, въ среду и въ пятокъ: да причтется къ 14 родовъ къ племени Вавилонскому.

Мъсяца декабря постися 4 недъди въ понедъдьникъ, въ среду и въ пятокъ: да причтется къ 14 родовъ рожству Христову. Зимнихъ дней.

Аще который человъкъ сохранитъ сиа 4 времена о хлъбъ и о водъ чистотою, постомъ, бдъниемъ, аще будутъ и велика сьгрђшениа, есть то въ едино или въ два льта, вся прегрбшениа отпустятся ему.

Аще вся 4 времена до живота своего съхранить сии постяся, да на страшнъмъ судищи никоего зда не убоится.

Сии же 4 времена увъдашя святии отци отъ Святаго Духа и уставишя постящимся въ кое время провидити то.

' $<$ One should $>$ fast in the first week of the month of March on Monday, Wednesday and Friday to be counted among the 14 generations of Abraham. Of the Spring days.

$<$ One should $>$ fast two weeks of the month of June on Monday, Wednesday and Friday to be counted among the 14 generations of David. Of the Summer days.

(32) М. Соколов, “Урочные посты" [Fixed fasts], Живая старина, 3 (1891), c. 213. 
$<$ One should $>$ fast three weeks of the month of September on Monday, Wednesday and Friday to be counted among the 14 generations of the tribe of Babylon. Of the Autumn days.

$<$ One should $>$ fast four weeks of the month of December on Monday, Wednesday and Friday to be counted among the 14 generations of Christ's Nativity. Of the Winter days.

If a man observes these four seasons on bread and water with chastity, fasting and vigil, if he even has great sins, whether in one or two years, all his sins will be forgiven him.

If he fasts all four seasons till the end of his life, he will not be afraid of any evil on the Judgment Day.

The Holy Fathers learned about these four seasons from the Holy Spirit and instructed those fasting when to observe them.'

One can easily detect here correspondences with the Twelve Fridays texts, especially with ABGKJ. Indeed, at the first glance it seems to be an excerpt from the Twelve Fridays legend, which preserves information only for those entries which, as we have seen, are to be linked to the Quattuor Tempora tradition. But that this is a completely separate text is shown by the fact that it speaks not of particular Fridays, but of fasting weeks. Of course, the numbers here are the result of (later?) corruption; one should reconstruct instead 'in the second week of June,' 'in the third week of September,' and 'in the fourth week of December.' With these slight emendations, we have a text completely fitting into the pattern of the Quattuor Tempora fasts. This leads to the suggestion that this text can be a faithful translation from a Latin (?) original, and in this case one may wonder if it or some parts of it could have been incorporated into the Twelve Fridays legend. And this question invites further considerations as to the origin and development of the legend. Since, as we have shown, the vestiges of Quattuor Tempora regulations are preserved only in a number of Slavic Twelve Fridays texts, and not in the whole corpus of them, it becomes an important criterion for distinguishing various recensions. However, it is tempting to speculate whether the Quattuor Tempora regulations were original to the Slavic version of the Twelve Fridays legend or were added later to some text(s). The fact that this version (or its vestiges) is attested to in the earliest Slavic texts, such as AMN, speaks in favor of QT being the intrinsic elements there. Contrarily, we should suppose that these elements were introduced by the copyists under the influence of the Latin tradition. Anyway, the very fact of inclusion of such a distinctly Western motif into a number of Slavic texts forces us to seek for a context and a milieu where this process could be justified. 
We can offer only some preliminary suggestions, but it seems significant that some of the earliest MSS containing the legend text point to a South Italian provenance. These include one of the oldest Latin texts from the MS Vat. lat. 1349 (10th-11th cent.) written in a characteristic Beneventan script, ${ }^{33}$ and, what is even more important, the earliest of the few Greek copies from the MS Vat. gr. 1276 (14th cent.) which was executed in the region of Otranto. ${ }^{34}$ The Greek text does not have any signs of 'seasonal' Fridays, but the same MS contains an anti-Latin polemical text attributed to Patriarch Nicolas III, ${ }^{35}$ and I think its occurrence along with the Twelve Fridays legend is not a coincidence. In particular, it addresses the question of observance of Quattuor Tempora, disregarded, as we have said, by the Eastern church. Particularly, it says that ${ }^{36}$

Au sujet du jeûne que (les Latins) observent aux quatre saisons de l'année, (nous disons qu') il est sans autorité, condamnable et réellement étranger aux lois et aux traditions qui fixent les jeûnes sacrés dans la sainte Eglise de Dieu.

Although the Latin custom of Quattuor Tempora fasts is here completely refuted, this instance shows, however, that it was known at least in the Southern Italian branch of the Eastern church and perhaps widely discussed as one of the points of disagreement between the two Christian churches. ${ }^{37}$

(33) On this MS see P. FOURNIER, “Un groupe de recueils canoniques italiens des Xe et XIe siècles," Mémoires de l'Académie des Inscriptions et BellesLettres, 40 (1915), p. 35; E. A. Loew, The Beneventan Script. A History of the South Italian Minuscule, Oxford, 1914, p. 362; L. Kéry, Canonical Collections of the Early Middle Ages (ca. 400-1140): A Bibliographical Guide to the Manuscripts and Literature (History of Medieval Canon Law, ed. by W. Hartmann, K. Pennington), Washington, D.C., 1999, pp. 196-197.

(34) On this MS see A. Acconcia Longo, A. JACOB, "Une anthologie salentine du XIVe siècle: Le Vaticanus gr. 1276," Rivista di studi bizantini e neoellenici, 17-19 (1980-1982), pp. 149-228. In fact, the only Greek text of the legend published so far also comes from the MS produced in Southern Italy, and namely in Mileto (Calabria), see Mercati, Note, pp. 238-239.

(35) This text was edited from this MS by J. DarrouzÈs, "Un faux acte attribué au patriarche Nicolas (III)," RÉB, 28 (1970), pp. 221-237.

(36) Translation by Darrouzès, “Un faux acte," p. 230.

(37) It should be noted that Quattuor Tempora were repeatedly mentioned in the polemical writings of the Eastern Church against the Western Church,

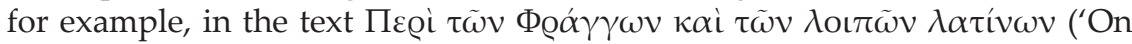


That the Latin tradition of the Twelve Fridays was connected to the Quattuor Tempora fasts can be demonstrated, for example, by the passage from the (unedited) copy contained in MS Medicea Laurenziana Plut. $45.23,^{38}$ and the number twelve was prominent in the exegesis of the Quattuor Tempora since Honorius Augustodunensis. ${ }^{39}$ However, it should be noted that in the Latin texts on the twelve Fridays we do not find such overt emphasis on Quattuor Tempora as in the Slavic ones. In fact, Quattuor Tempora are constantly mentioned only in connection with the sixth Friday (in June), ${ }^{40}$ and the references to any other Quattuor Tempora fasts are very rare. ${ }^{41}$

Nevertheless, the combined evidence of the earliest Latin and Greek MSS as well as the fact that the earliest Slavic - both Glagolitic and Cyrillic - MSS mentioning 'seasonal' Fridays have a Serbian and Croatian (not, for example, Bulgarian or Moravian) origin make the

the Franks and other Latins') which was widely known in Slavic MSS from the thirteenth century onwards, but what is condemned here is not the custom of Quattuor Tempora fasts, but the custom of ordaining deacons and bishops only during Quattuor Tempora weeks (See A. Попов, Историко-литературный обзор древне-русских полемических сочинений против латинян (XI-XV в.) [A historical-critical survey of the Old Russian polemical writings against the Latins (11th-15th cent.)], Москва, 1875, с. 68, 324).

(38) "Istis xii diebus de iiiior tempora anni sunt de carne non comedant neque de pisce et uinum non bibant."

(39) Cf. Gemma animae: “De jejunio Quatuor Temporum de lege est acceptum. Ideo autem quatuor temporibus observatur, quia quatuor tempora anni, scilicet ver, aestas, autumnus, hiems numerantur. Ideo autem in unoquoque tres dies, qui conjuncti duodecim fiunt, quia duodecim menses in uno anno sunt" (PL 172, cols. 684-5).

(40) In a vast majority of Latin MSS, to name just a few: Bordeaux, Bibliothèque Municipale 11; Corpus Christi College, Cambridge Ms. 320; Benediktinerabtei Sankt Georgenberg-Fiecht, Codex 113; Bibliothèque Nationale, Lat. 2774; British Library, Additional 16975; Biblioteca Apostolica Vaticana, Vat. lat. 1349. For the bibliography see Ivanov, "The Legend of Twelve Golden Fridays."

(41) In fact, I have found only one instance in MS A 454, Bibliothèque de Rouen: "x. prima Veneris septembris, est dies Veneris .iiijor. temporum septembris" (See P. Meyer, "Notice du Ms. A 454 de la Bibliothèque de Rouen," Bulletin de la Société des anciens texts français, 9 (1883), pp. 97-98). However, a unique example of the term Quattuor Tempora was used as a cover term for the twelve Fridays in the aforementioned MS Biblioteca Medicea Laurenziana, Plut. 45.23: "Istis xii diebus de iiiior tempora anni sunt de carne non comedant neque de pisce et uinum non bibant." 
area of Southern Italy and the Adriatic the most probable zone of contacts where the Quattuor Tempora tradition could have penetrated into the Twelve Fridays legend. The reason for this development is obscure, but it may well be that it resulted from an attempt to bring the fasting regulations of the Eastern church closer to the Western customs.

\section{SUMMARY}

In this study I tried to show that a curious designation "временная" (seasonal) applied to some Fridays in the Slavic version of the Twelve Fridays legend, is to be derived from the Western fasting regulations known as Quattuor Tempora. 